\title{
Levels of polycyclic aromatic hydrocarbons and polychlorinated biphenyls in sediment of bitumen deposit impacted area
}

\author{
*E. O., Fagbote: E. O. Olanipekun \\ Department of Chemistry, University of Ado-Ekiti, Nigeria \\ Received 29 January 2010; ～revised 15 March 2010; accepted 22 May 2010; available online 1 June 2010
}

\begin{abstract}
Polycyclic aromatic hydrocarbons and polychlorinated biphenyls were investigated in sediment of bitumen deposit impacted area of Agbabu, Nigeria, to determine the present level of contamination with these toxic compounds prior to exploitation. Samples were collected during the dry season (March) and the wet season (August) of year 2008. Analysis was carried out with gas chromatography using mass spectrometry detector for polycyclic aromatic hydrocarbons and flame ionization detector for polychlorinated biphenyls. In the dry season sum of concentration of PAHs ranged from zero to $0.12 \pm 0.06 \mathrm{ppm}$, while in the wet season the minimum was $0.18 \pm 0.07 \mathrm{ppm}$ and the maximum was $1.04 \pm 0.16 \mathrm{ppm}$. Most of these values were higher than sum of polycyclic aromatic hydrocarbons concentrations of $1-10 \mu \mathrm{g} / \mathrm{kg}$ indicating that they were likely to come from anthropogenic sources. Average concentrations of PAHs such as naphthalene and benzo (a) pyrene obtained in sediment in the wet season in some of the stations were higher than recommended limits. The linear regression analysis between sum of concentrations and percentage organic carbon showed no significant correlation in sediment in the dry season $\left(r^{2}=0.0025\right)$ and in the wet season $\left(r^{2}=0.1345\right)$. The predominance of 4-6 ringed polycyclic aromatic hydrocarbons and the ratios between pairs of individual polycyclic aromatic hydrocarbons showed that they are likely to have come from pyrolytic sources. No polychlorinated biphenyl congener was detected in the samples.
\end{abstract}

Keyword: Agbabu; Anthropogenic; Gas chromatography; Pyrolytic; Season

\section{INTRODUCTION}

Bitumen is a mixture of organic liquids that are highly viscous and entirely soluble in carbon disulphide (Rajput, 2000) and composed of primarily highly condensed polycyclic aromatic hydrocarbons. Bitumen was discovered in Nigeria over a hundred years ago, preceding the discovery of oil by over 50 years. The Nigerian bitumen belt lies on the onshore areas of Eastern Dahomey (Benin) basin. Nigeria has a proven reserve of 42.47 billion metric tonnes, the second largest in the world, covering about $120 \times 4.3$ $\mathrm{km}$ (Oboh et al., 2006). This is spread along the bitumen belt stretching from Lagos, Ogun and to Ondo and Edo states. Five distinct hydrocarbon types of occurrence have been identified within the tar sands belt: outcrop, rich sands, lean sands, shale and deep seated heavy crude. Between 1904 and 1970, close to 40 wells, boreholes and exploration wells had been drilled within the area of surface occurrence. One of the wells, NBC-7 located at Agbabu village remains

*Corresponding Author Email: bunmifag@yahoo.com Tel./Fax: :+2347035483300 open to the surface and periodically flow heavy oil. The area surrounded by Foriku to the north, Agbabu to the north, Aiyabi to the east and the railhead to the west is very rich in bituminous deposits. The net thickness of the sections range between $4 \mathrm{~m}$ and $32 \mathrm{~m}$ with relatively thin overburden sections and consequently good 'stripping potential'.

Agbabu is a village of about 400 inhabitants at the south-western part of Nigeria in the coordinates of E004 $48-49^{1}$ and N06 ${ }^{0} 34-36^{1}$ (Fig. 1). This is where bitumen was first spotted in Nigeria in 1910 and the first bitumen well NBC-7 was drilled there. Temidire is a smaller village of about 200 people located very close to Agbabu. There is an old tarred road running from the north end, which is the only entrance into the village by land, through the village and ends up in a large tarred space at the south end.

This large area at the south end showed more signs of contamination because it was used for loading and off-loading of petroleum products about ten years ago. Farmers at Agbabu area deal mainly in cash crops such 
as cocoa and colanut and food crops such as yam and plantain and fishing along Oluwa River which flows through the whole land. These villagers depend on Oluwa River for their farming activities and other domestic uses while hand dug shallow wells serve as their only source of potable water. Temperature remains moderate throughout the year in the area with a minimum around $24^{\circ} \mathrm{C}$ and the maximum around $33^{\circ} \mathrm{C}$. The two distinct seasons in the year are wet and dry. The wet season is at its peak from July to the middle or September while the dry season is from January to March.

Bitumen contains very small quantities of Polycyclic aromatic hydrocarbons (PAHs) having $4-6$ condensed rings. When bitumen is in its natural state, the PAHs are not bio-available, but when it is used in a mixture with other solvents that can dissolve it, the PAHs can be released into the environment (Bitumen Safety Data Sheet, 2008; Fouial -Djebbar et al., 2010). The effects of PAHs on human health depend on the concentration, type and extent of exposure.

PAHs compounds contain complex chemicals which include carbon and hydrogen with a fused ring, structure containing at least two benzene rings. The carbon atoms are arranged in a series of adjoining sixmembered rings. Their biochemical persistence in the environment arises from dense clouds of $\pi$ electrons on both sides of the ring structures making them resistant to neucleophilic attack (Jonsen et al., 2005; Nnamchi et al., 2006). PAHs have been documented to cause several health problems (Zhang et al., 2009). Some PAHs and their derivations are highly toxic (Okafor and Opuene, 2007; Juang et al., 2009). Their mutagenic or carcinogenic properties are the main risk to human health (Ciecierska and Obiedzinski, 2007; Prycek et al., 2007).

Polychlorinated biphenyls (PCBs) are a class of organic compounds having a basic chemical structure, which include two benzene (biphenyl) rings and between 1 and 10 chlorine atoms substituted on each of the benzene molecule (ATSDR, 2001). There are 209 congeners of PCBs. There are no known natural sources of PCBs. They are synthetic organic chemicals called Aroclors used in a variety of materials to enhance insulation properties, improve physical and chemical resistance and act as plasticizers, coolants and lubricants. Some manufacturing processes which involve hydrocarbons, chlorine and heat such as

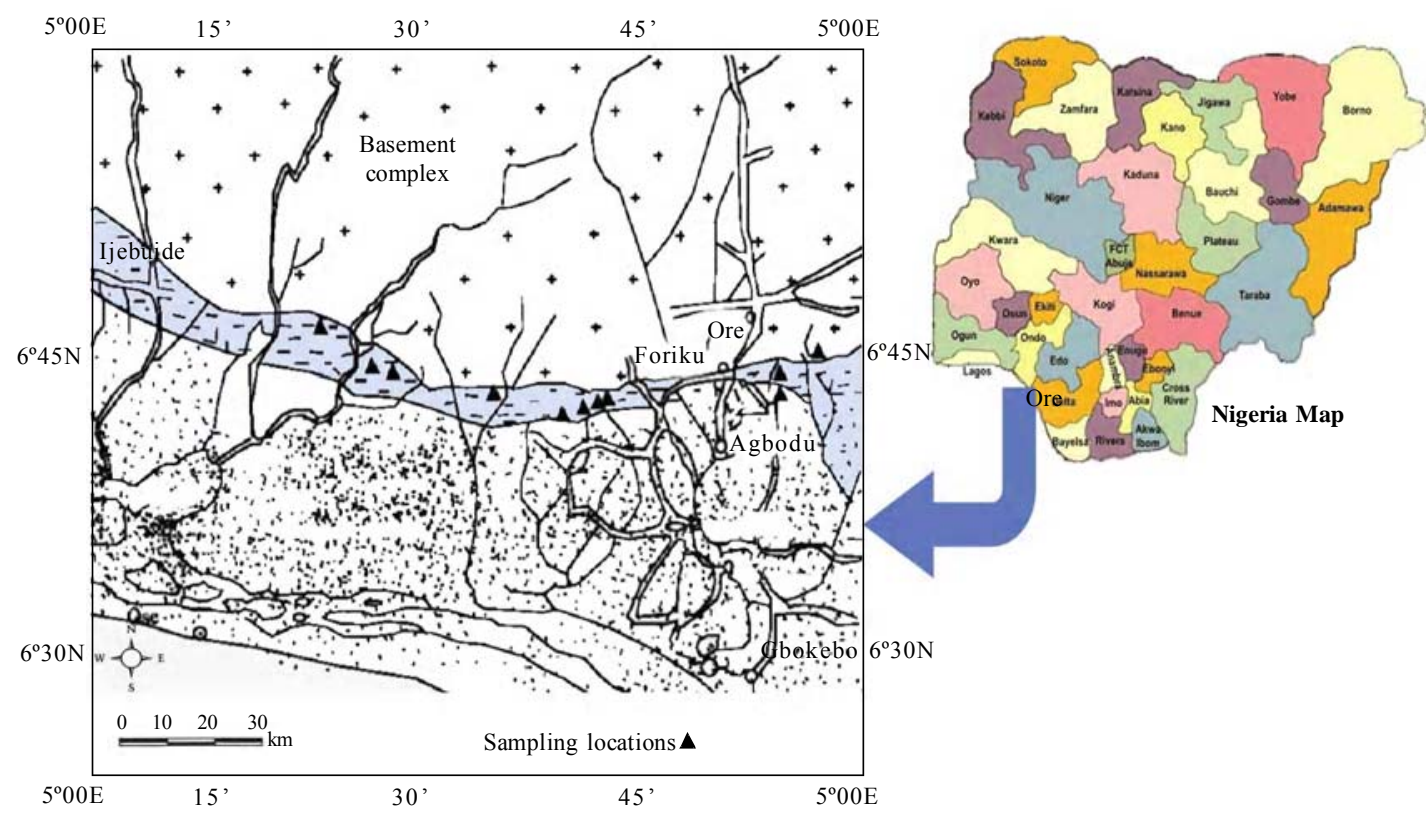

Fig. 1: Map of Nigeria showing Agbabu location point 
production of chlorinated solvents, paints, printing inks, agricultural chemicals, plastics and detergent bars also generate PCBs (Fact sheet sources of polychlorinated biphenyls, 2003). Major sources of PCBs in Nigeria include importation of electrical transformer oils. Other sources are anthropogenic activities such as agriculture, discharge of industrial waste into rivers and incineration (Adeyemi et al., 2009). Despite the relatively low volatility of PCBs, they do volatilize from both soil and water to air and travel over long distances before they are re-deposited by settling or scavenging by precipitation. Studies on both human and laboratory manuals provide strong evidence of the toxic potential of exposure to PCBs. The health effects include liver, thyroid, dermal and ocular changes, reduced birth weight, reproductive toxicity and cancer (Adeyemi et al., 2009).

Multi-elemental analysis of Nigerian bitumen and the physical constants characterization of its hydrocarbon content have been carried out (Adebiyi et al., 2006). Very high enrichment factors were obtained for $\mathrm{V}, \mathrm{Cr}, \mathrm{Ni}, \mathrm{Cu}, \mathrm{Zn}, \mathrm{As}$ and $\mathrm{Pb}$. Environmental impact assessment of steam injection mining method of Agbabu bitumen deposit has been reported (Akande, 2007). The distribution of PAHs in water and soil sample from the vicinity of Agbabu bitumen field has also been studied using GC-FID (Abass et al., 2007). n-Alkanes distribution in soil and water samples collected near Agbabu bitumen field of southwestern Nigeria has been reported (Olajire et al., 2008). Evaluation of the status of heavy metal pollution of sediment of Agbabu bitumen deposit area, Nigeria, has been reported (Fagbote and Olanipekun, 2010). Environmental implications of bitumen seep induced pollution in parts of Ogun state, southwestern Nigeria has been studied (Adewole, 2010). The results indicated exceptionally high concentration of both total hydrocarbon and polynuclear aromatic hydrocarbons in all types of samples in varying degrees when compared to the standard values.

The distributions of PAHs in sediment and PCBs in any of the environmental components in Agbabu bitumen deposit IMPACTED area have not been reported. Agbabu bitumen deposit area is presently characterized with seepages. The impact of bitumen seepages on the Nigerian physical environment may be enormous (Adewole, 2010). There are some exploration wells in the area presently which may introduce some of the toxic substances to the environment, though full exploitation has not commenced. The aim of this research was to determine the level of contamination of sediment of Agbabu bitumen deposit with polycyclic aromatic hydrocarbons and polychlorinated biphenyls because sediment is a natural sink of pollutants (Davies and Abowei, 2009; Rauf et al., 2009; Ho et al., 2010). Sediment is able to keep contaminants only to be released to the water body over time (Kyn et al., 2009). PCBs may not be formed presently in the environment. Also, though PAHs form part of the components of bitumen, they are not bioavailable in the natural state. During exploitation of bitumen it is expected that enormous quantities of both PAHs and PCBs will be introduced into the environment anthropogenically. Knowing the present level of contamination of these toxins in sediment is necessary because apart from the little that can be introduced from the wells and the seepages now, they can also be formed somewhere else and transported through flowing river and air and be deposited in the environment. The present knowledge of the status of pollution will form a baseline data and a guide on how anthropogenic activities of exploitation will be controlled proactively to introduce less of the toxic substances. In this study, investigation of the levels of PAHs and PCBs in sediment, were carried out. GC/ MS was used to detect and quantify PAHs because it is more selective (Soltanali and Shams Hagani, 2008) while GC-FID used for PCBs due to its higher sensitivity.

This research was carried out at Agbabu bitumen deposit area, south western Nigeria, in the months of March (dry season) and August (wet season) 2008.

\section{MATERIALS AND METHODS}

Sediment samples were collected at five points along the bottom of River Oluwa that flows across Agbabu community

\section{Sampling}

- In the dry season (March 2008);

- Number of samples collected for PAH $=5$

- Number of samples collected for PCB $=5$

- In the wet season (August 2008)

- Number of samples collected for PAH $=5$

- Number of samples collected for PCB $=5$

- Sampling points were geo-located with global positioning system (GPS) to ensure consistency. 


\section{Sample handling}

Sediment samples were collected with clean samplers from sediment immediately below the water body $(0-$ $200 \mathrm{~mm}$ ) and wrapped with aluminium foil to prevent contamination, kept in dry ice and transported to the laboratory and stored at $-20^{\circ} \mathrm{C}$. Samples were then oven dried at $150{ }^{\circ} \mathrm{C}$ to $200{ }^{\circ} \mathrm{C}$ for a minimum of $30 \mathrm{~min}$, homogenized and sieved through a mesh of $2 \mathrm{~mm}$ to remove stones and other debris and stored at $-20{ }^{\circ} \mathrm{C}$. Samples were extracted within 7 days after sampling and analyzed within 40 days after extraction.

\section{Analysis methods}

PAHs in samples were identified and quantified using Agilent $6890 \mathrm{~N}$ gas chromatograph coupled with mass spectrometer (Elaine and Herman, 2000). All glass wares were cleaned by detergent washing and hot water and rinsed with distilled water.

\section{Extraction}

Samples were dried at $105^{\circ} \mathrm{C}$, grinded and sieved with $1 \mathrm{~mm}$ sieve before extracting with soxlet extractor using dichloromethane as extraction solvent. Samples were concentrated using Kuderna Danish (K-D) concentrator. Relative dark and thickly concentrated samples were cleaned by diluting the extract with dichloromethane since such samples were capable of causing interference and contamination to the GC column.

\section{To prepare $P A H$ standard mixture}

$25 \mu \mathrm{L}, 50 \mu \mathrm{L}, 75 \mu \mathrm{L}, 100 \mu \mathrm{L}$ and $150 \mu \mathrm{L}$ of $200 \mu \mathrm{g} / \mathrm{mL}$ PAH stock standard solution was added into separate vials. $50 \mu \mathrm{L}, 100 \mu \mathrm{L}, 150 \mu \mathrm{L}, 200 \mu \mathrm{L}$ and $300 \mu \mathrm{L}$ of 100 $\mu \mathrm{g} / \mathrm{mL}$ surrogate standard (pyrene $\mathrm{d} 10$ ) were added in each vial and the final volume was made up to $10 \mathrm{~mL}$ with dichloromethane. QC standard mixture of $30 \mu \mathrm{g} /$ $\mathrm{mL}$ in dichloromethane was prepared. The sample extract were finally analyzed on the Agilent $6890 \mathrm{~N}$ with adequate quality control.

\section{Analysis}

Sample extracts were analyzed using Agilent 6890N

- $3 \mu \mathrm{L}$ of methylene chloride was injected as a blank sample

- $3 \mu \mathrm{L}$ of extract after concentration was injected into the injection port

- Extract peaks generated that were above scale were diluted with methylene chloride and re-analyzed.
Method detection limit is $<0.01 \mathrm{ppm}$ for Benzo $(\mathrm{k})$ fluoranthene, $<0.03 \mathrm{ppm}$ for Benzo $(\mathrm{g}, \mathrm{h}, \mathrm{I})$ perylene AND $<0.02 \mathrm{ppm}$ for naphthalene, 2methylnaphthalene, acenapthylene, acenaphthene, fluorene, phenanthrene, anthracene, fluoranthene, pyrene, benzo (a) anthracene, chrysene, benzo (b) fluoranthene, benzo(a)pyrene, dibenzo (a, h) anthracene, indeno(1,2,3-d) pyrene.

GC oven program for $\mathrm{PAH}$ is as follows: Column type $-30 \mathrm{~m} \times 0.25 \mathrm{~mm}$ ID $\times 0.25 \mu \mathrm{m}$ film thickness siliconecoated fused-silica capillary column (DB-5 or HP-5)

Oven - On Set point $-65^{\circ} \mathrm{C}$ Initial Temp - $65^{\circ} \mathrm{C}$ hold for 1 minute $65^{\circ} \mathrm{C}$ to $140^{\circ} \mathrm{C} @ 15^{\circ} \mathrm{C} /$ minute for 4 minutes Final Temp - 40 to $290^{\circ} \mathrm{C} @ 10^{\circ} \mathrm{C} /$ minute hold for 10 $\min$. To validate the procedure the following quality controls were observed:

- A solvent blank was run every day prior to analysis

- After every 20 samples, a sample was run as duplicate

- The relative percent difference (RPD \%) was determined as follows:

$\% \mathrm{RPD}=[2(\mathrm{D} 1-\mathrm{D} 2) /(\mathrm{D} 1+\mathrm{D} 2)] \times 100$

Where $\mathrm{D} 1=$ Concentration of the analyte in the first duplicate sample

- D2 = Concentration of the analyte in the second duplicate sample

A mid-point calibration was run after every 20 samples

- When recovery was not within $80-120 \%$, it was checked to be sure that there were no errors in the calculation. Otherwise it was re- analyzed.

- For each sample analyzed, the percentage recovery of each surrogate was calculated

- If recovery was not within $40-120 \%$, it was checked to be sure that there were no errors in the calculation, surrogate solutions. Otherwise sample was re-extracted and re-analyzed

- Freshly packed chromatographic column was used for each sample during sample clean-up.

- Cotton and glass wool were pre-treated by washing with dichloromethane before use.

(2) PCBs in samples were analyzed using GC 610 connected to FID (Clescery et al., 1989).

\section{Extraction}

Sample preservation, extraction, concentration and clean up for sediment samples were carried out in the same procedure for PAH. 
Analysis

$0.1 \mu \mathrm{L}$ of extract after concentration was injected into the injection port of the FID. The column was thoroughly flushed between runs with extraction solvent, using the same operational methods that were used for calibration. Extract peaks generated that were above scale were diluted with dichloromethane and reanalyzed. Method detection limit for PCBs is $<0.01$ ppm.

\section{GC oven program for $\mathrm{PCB}$ is as follows}

Column type $-30 \mathrm{~m} \times 0.25 \mathrm{~mm}$ ID $\times 0.25 \mu \mathrm{m}$ film thickness silicone-coated fused-silica capillary column (DB-5 or HP-5)

Oven - On Set point $-125^{\circ} \mathrm{C}$ Initial Temp $-125^{\circ} \mathrm{C}$ hold for $3 \mathrm{~min}$ Final Temp $-125^{\circ} \mathrm{C}$ to $270^{\circ} \mathrm{C} @ 12^{\circ} \mathrm{C} / \mathrm{min}$ hold for $2 \mathrm{~min}$. Procedure was validated as in $1 \mathrm{~B}$ above:

- Organic carbon was determined by the wet combustion method

- $1.00 \mathrm{~g}$ of finely ground sediment was weighed into a labeled dry Erlenmeyer flask of $400 \mathrm{~mL}$ capacity

- Another clean dry 500 mL Erlenmeyer flask was set up as blank. All flasks were placed on top of white tiles.

- $10 \mathrm{~mL}$ of $1 \mathrm{~N} \mathrm{~K}_{2} \mathrm{Cr}_{2} \mathrm{O}_{7}$ was weighed accurately into each flask and swirled gently to dispense the sediment.

- Using an acid dispenser set, $20 \mathrm{~mL}$ of conc. $\mathrm{H}_{2} \mathrm{SO}_{4}$ was rapidly added into the suspension (sample and blank). Flasks were gently rotated to effect complete mixing of sample and reagents in the flask.

- The flasks were allowed to stand for $30 \mathrm{~min}$.

- $200 \mathrm{~mL}$ of distilled water was added to the contents of each flask

- $10 \mathrm{~mL}$ of $\mathrm{H}_{3} \mathrm{PO}_{4}$ was dispensed into the flasks and swirled gently.

- Using an automatic pipette, $1 \mathrm{~mL}$ of Diphenylamine indicator was added.

- Suspension was titrated with $0.5 \mathrm{~N} \mathrm{FeSO}_{4}$ until the color changed from turbid blue to brilliant green.

\section{RESULTS AND DISCUSSION}

Table 1 shows the average concentrations, sum of concentration of PAHs and ratios of PAHs in sediment in dry season (March 2008). Table 2 shows the average concentrations, sum of concentration of PAHs and ratios of PAHs in sediment in wet season (August 2008). No PCB congener was detected in both dry and wet seasons. In the dry season no PAH was detected at OLSW2 (SED) while the minimum $\Sigma$ PAH concentrations was found in OLSW3- SED $(0.02 \pm$ $0.01 \mathrm{ppm}$ ) and the maximum was found in OLSW1-SED $(0.12 \pm 0.06 \mathrm{ppm})$. In the wet season the minimum $\Sigma \mathrm{PAH}$ concentrations was found in OLSW4- SED $(0.18 \pm$ $0.07 \mathrm{ppm}$ ) while the maximum was found in OLSW1$\operatorname{SED}(1.04 \pm 0.16 \mathrm{ppm})$.

From the results, Agbabu bitumen deposit area as at the time of the research was not polluted by PCBs.

Table 1: Average concentration, sum of pahs in sediment and ratios of pahs (dry season - March)

\begin{tabular}{|c|c|c|c|c|c|c|c|}
\hline S. No & Name of PAH & & $\begin{array}{c}\text { OLSW1 } \\
\text { (SED) } \\
\text { ppm }\end{array}$ & $\begin{array}{c}\text { OLSW2 } \\
\text { (SED) } \\
\text { ppm }\end{array}$ & $\begin{array}{c}\text { OLSW3 } \\
\text { (SED) } \\
\text { ppm }\end{array}$ & $\begin{array}{l}\text { OLSW4 (SED) } \\
\text { ppm }\end{array}$ & $\begin{array}{c}\text { AGMILE2 (SED) } \\
\text { ppm }\end{array}$ \\
\hline 1 & Benzo (b) flouranthene & 5 rings & $0.04 \pm 0.01$ & ND & ND & $0.02 \pm 0.020$ & $0.02 \pm 0.004$ \\
\hline 2 & Benzo (k) flouranthene & & $0.05 \pm 0.03$ & ND & ND & $0.02 \pm 0.012$ & $0.03 \pm 0.010$ \\
\hline 3 & Benzo (a) pyrene & & $0.03 \pm 0.02$ & ND & $0.02 \pm 0.01$ & $0.03 \pm 0.013$ & $0.03 \pm 0.020$ \\
\hline 4 & Benzo $(g, h, i)$ perylene & & ND & ND & ND & ND & ND \\
\hline 5 & Dibenzo $(\mathrm{a}, \mathrm{h})$ anthracene & & ND & ND & ND & ND & ND \\
\hline $\begin{array}{l}6 \\
\text { Sum PAHs } \\
\% \text { Org. }\end{array}$ & Indeno $(1,2,3$-cd) pyrene & $\begin{array}{l}\text { Sum } \\
6 \text { rings }\end{array}$ & $\begin{array}{r}\text { ND } \\
0.12 \pm 0.06\end{array}$ & $\begin{array}{r}\text { ND } \\
0\end{array}$ & $\begin{array}{c}\mathrm{N} \\
0.02 \pm 0.01\end{array}$ & $\begin{array}{r}\text { ND } \\
0.07 \pm 0.045\end{array}$ & $\begin{array}{r}\text { ND } \\
0.08 \pm 0.034\end{array}$ \\
\hline $\begin{array}{l}\text { Carbon } \\
\text { RATIOS } \\
\text { OF PAHs }\end{array}$ & & & $1.11 \pm 0.01$ & $1.05 \pm 0.01$ & $4.12 \pm 0.12$ & $4.18 \pm 0.020$ & $3.76 \pm 0.150$ \\
\hline $\mathrm{BBF} / \mathrm{BKF}$ & & & 0.80 & ND & ND & 1.00 & 0.67 \\
\hline $\mathrm{BKF} / \mathrm{BaP}$ & & & 1.67 & ND & ND & 0.67 & 1.00 \\
\hline $\mathrm{BBF} / \mathrm{BaP}$ & & & 1.33 & ND & ND & 0.67 & 0.67 \\
\hline
\end{tabular}

$\mathrm{ND}=$ Not detectable 
E. O. Fagbote; E. O. Olanipekun

Table 2: Average concentration, sum of pahs in sediment and ratios of pahs (wet season - August)

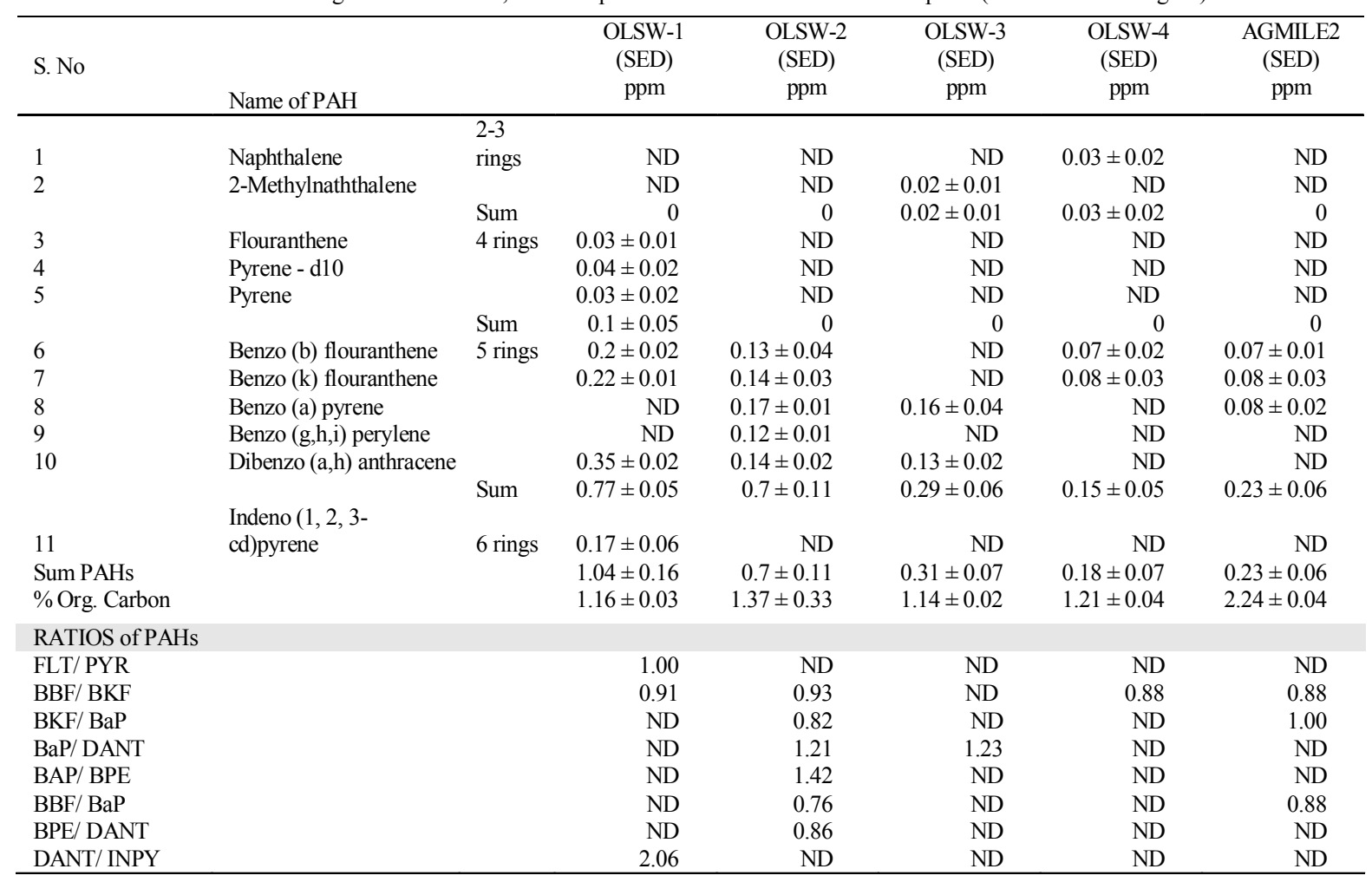

This is because there are no natural sources of PCBs and there were no anthropogenic activities that would have introduced PCBs to the environment. Also the area is still free of PCBs because none has been transported there. It was necessary to know the status of PCBs in the environment because despite the relatively low volatility of $\mathrm{PCBs}$, they do volatilize from both soil and water to air and travel over long distances before they are re-deposited by settling or scavenging by precipitation (Adeyemi et al., 2009). If PCBs are found in the environment after commencement of exploitation, then apparently it is not a release from sediment and it will be easier to know the sources and control them proactively.

The sums of concentrations of PAHs in sediment were higher in the wet season than in the dry season probably due to rainfall and runoff. This is in agreement with the results of Teaf(2008). Emissions from a host of mechanisms including storm water runoff, direct deposition, and surface runoff from roadways and discharges from boats contribute heavily to aquatic sediment contamination.
OLSW1 is the most polluted sampling point with PAHs in the dry and wet seasons. PAHs must have contaminated the sediment in this area more during loading and offloading of petroleum activities by trucks that took place through this point about ten years ago. The most predominant PAHs in sediment at Agbabu bitumen deposit were 4-6 ring PAHs as shown in Tables 1 and 2. The predominance of 4-6 ring PAHs indicates that they were likely to be formed by pyrolysis (i.e. anthropogenic combustion). 2 or 3 rings PAHs are usually from petrogenic (i.e. production, transport and use of petroleum and its refined products) sources while 4-6rings PAHs are from pyrolytic sources.

The level of contamination of sediment in this environment with PAH was assessed based on the Recommended Interim Sediment Quality criteria of Environmental Protection Department, province of the British Columbia. A significant factor that controls the concentration of PAHs in sediment is total organic carbon (Opuene et al., 2007). The organic carbon of sediments determines the sorption of organic molecules. This forms the basis of the partitioning 
concept of sediment sorption. The recommended limit of PAH of sediment containing organic carbon content above $1 \%$ of organic carbon content can be determined. Since the organic carbon content was above $1 \%$, the appropriate criteria can be obtained by multiplying the given values recommended in the table of interim sediment quality criteria of environmental Protection Department, Province of the British Columbia, by the percent organic carbon content of the sediment obtained in this study. The values obtained are now compared with the concentrations of the individual PAH in each station as shown in Table 3 (Dry season) and Table 4 (Wet season) (Nagpal, 1994).

Most of the PAH concentrations obtained for sediment were lower than the recommended limit but the average concentrations obtained for sediment in the wet season of $0.03 \pm 0.01 \mathrm{ppm}$ for naphthalene at OLSW3 (SED) was above the recommended limit of $0.012 \mathrm{ppm}, 0.17 \pm 0.01 \mathrm{ppm}$ obtained for benzo (a) pyrene at OLSW2 (SED) was higher than $0.08 \mathrm{ppm}$ recommended and $0.16 \pm 0.04 \mathrm{ppm}$ obtained for benzo (a) pyrene at OLSW3 (SED) was higher than $0.068 \mathrm{ppm}$ recommended. Naphthalene that is present in this area above the recommended limit is in the group of 2-3 rings, while benzo (a) pyrene) that is the most abundant in the environment above the recommended limit is in group 4-6 rings. Several PAHs containing 2-3 aromatic rings have significant acute toxicity to aquatic organisms and the ones containing 4-6 aromatic rings in their structure, are known to be mutagenic, carcinogenic and inducers of tumors in manuals. Aquatic organisms can accumulate PAHs from water, sediment and food (Nagpal, 1994).

The linear regression analysis between mean concentrations and percentage organic carbon was carried out in this study and the results are shown in Figs. 2 and 3. Fig. 2 for the dry season is obtained from the values in Table 5 while Fig. 3 for the wet season was obtained from the values in Table 6 . The linear regression analysis showed no significant correlation in sediment in the dry season $\left(r^{2}=0.0025\right.$ for sediment $)$ and for sediment in the wet season $\left(r^{2}=0.1345\right)$. This shows that the sites were specifically contaminated to different levels. This also means that contamination of sediment with PAH in the area is from various anthropogenic sources. The most significant sources of PAHs in an environment can be known with the ratios between pairs of concentrations of individual PAHs.

Table 3: Recommended sediment quality criteria (dry season)

\begin{tabular}{|c|c|c|c|c|c|c|}
\hline PAH & $\begin{array}{l}\text { Sediment criteria } \\
(\mu \mathrm{g} \text { PAH/g dry wt) }\end{array}$ & $\begin{array}{l}\text { OLSW1 } \\
\text { (SED) }\end{array}$ & $\begin{array}{c}\text { OLSW2 } \\
\text { (SED) }\end{array}$ & $\begin{array}{c}\text { OLSW3 } \\
\text { (SED) }\end{array}$ & $\begin{array}{c}\text { OLSW4 } \\
\text { (SED) }\end{array}$ & $\begin{array}{l}\text { AGMILE' } \\
\text { (SED) }\end{array}$ \\
\hline Naphthalene & 0.01 & 0.0111 & 0.0105 & 0.0412 & 0.0418 & 0.0376 \\
\hline Acenaphthylene & 0.15 & 0.1665 & 0.1575 & 0.618 & 0.627 & 0.564 \\
\hline Flourene & 0.2 & 0.222 & 0.21 & 0.824 & 0.836 & 0.752 \\
\hline Anthracene & 0.06 & 0.0666 & 0.063 & 0.2472 & 0.2508 & 0.2256 \\
\hline Phenanthrene & 0.04 & 0.0444 & 0.042 & 0.1648 & 0.1672 & 0.1504 \\
\hline Acridine & 1 & 1.11 & 1.05 & 4.12 & 4.18 & 3.76 \\
\hline Flouranthene & 2 & 2.22 & 2.1 & 8.24 & 8.36 & 7.52 \\
\hline Chrysene & 0.2 & 0.222 & 0.21 & 0.824 & 0.836 & 0.752 \\
\hline Benzo (a) Anthracene & 0.2 & 0.222 & 0.21 & 0.824 & 0.836 & 0.752 \\
\hline Benzo (a) pyrene & 0.06 & 0.0666 & 0.063 & 0.2472 & 0.2508 & 0.2256 \\
\hline$\%$ Org. Carbon & & 1.11 & 1.05 & 4.12 & 4.18 & 3.76 \\
\hline
\end{tabular}

Table 4: Recommended sediment quality criteria (wet season)

\begin{tabular}{|c|c|c|c|c|c|c|}
\hline PAH & $\begin{array}{l}\text { Sediment criteria } \\
(\mu \mathrm{g} \mathrm{PAH} / \mathrm{g} \text { d.wt })\end{array}$ & $\begin{array}{l}\text { OLSW1 } \\
\text { (SED) }\end{array}$ & $\begin{array}{l}\text { OLSW2 } \\
\text { (SED) }\end{array}$ & $\begin{array}{l}\text { OLSW3 } \\
\text { (SED) }\end{array}$ & $\begin{array}{l}\text { OLSW4 } \\
\text { (SED) }\end{array}$ & $\begin{array}{c}\text { AGMILE } \\
\text { 2(SED) }\end{array}$ \\
\hline Naphthalene & 0.01 & 0.0116 & 0.0137 & 0.0114 & 0.0121 & 0.0224 \\
\hline Acenaphthylene & 0.15 & 0.174 & 0.2055 & 0.171 & 0.1815 & 0.336 \\
\hline Anthracene & 0.06 & 0.0696 & 0.0822 & 0.0684 & 0.0726 & 0.1344 \\
\hline Phenanthrene & 0.04 & 0.0464 & 0.0548 & 0.0456 & 0.0484 & 0.0896 \\
\hline Acridine & 1 & 1.16 & 1.37 & 1.14 & 1.21 & 2.24 \\
\hline Chrysene & 0.2 & 0 & 0 & 0 & 0 & 0 \\
\hline Benzo (a) Anthracene & 0.2 & 0.232 & 0.274 & 0.228 & 0.242 & 0.448 \\
\hline Benzo (a) pyrene & 0.06 & 0.0696 & 0.0822 & 0.0684 & 0.0726 & 0.1344 \\
\hline$\%$ Org. Carbon & & 1.16 & 1.37 & 1.14 & 1.21 & 2.24 \\
\hline
\end{tabular}


PAHs and PCBs in sediment of bitumen impact area

Table 5: The linear regression analysis between sum of concentrations of PAHs and \% sediment organic carbon (Dry season)

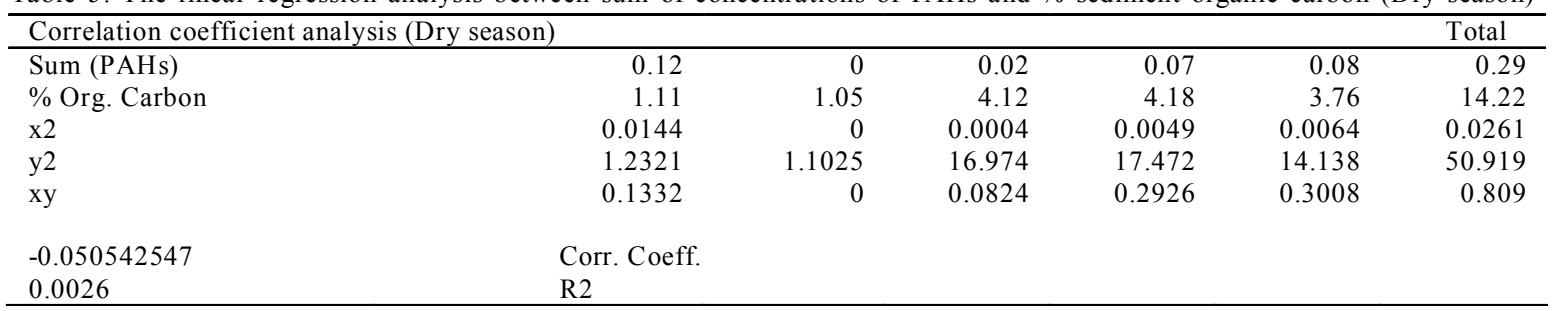

Table 6: The linear regression analysis between sum of concentrations of PAHs and \% sediment organic carbon (Wet season)

\begin{tabular}{lrrrrr}
\hline Correlation coefficient analysis (Wet season) & & & & \\
\hline Sum (PAHs) & 1.04 & 0.7 & 0.3 & 0.18 & 0.2 \\
\% Org. Carbon & 1.16 & 1.37 & 1.1 & 1.21 & 2.2 \\
x2 & 1.0816 & 0.49 & 0.1 & 0.03 & 0.1 \\
y2 & 1.3456 & 1.88 & 1.3 & 1.46 & 5 \\
xy & 1.2064 & 0.96 & 0.4 & 0.22 & 0.5 \\
-0.366715196 & Corr. Coeff. & & & & \\
0.134480035 & R2 & & & & \\
\hline
\end{tabular}

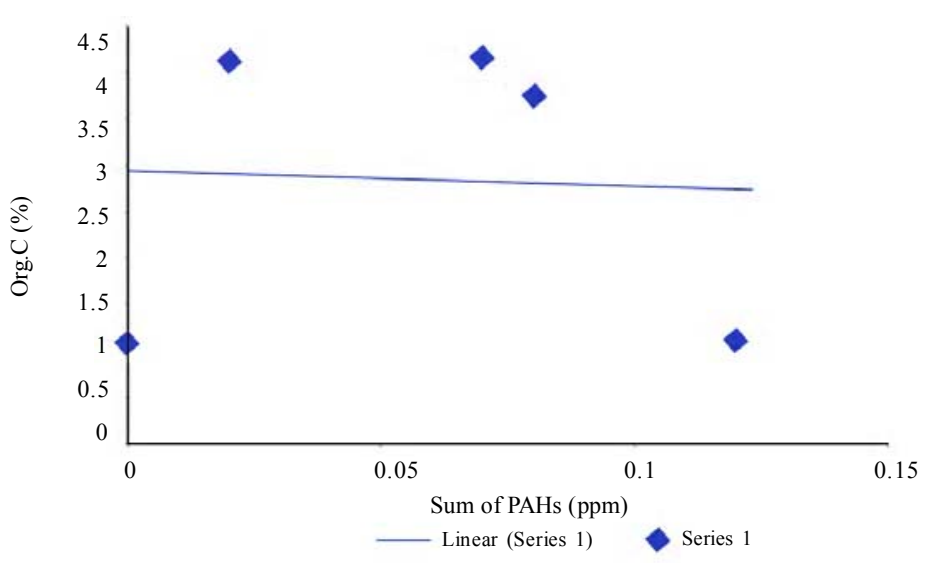

Fig. 2: Sediment dry season $\left(r^{2}=0.0025\right)$

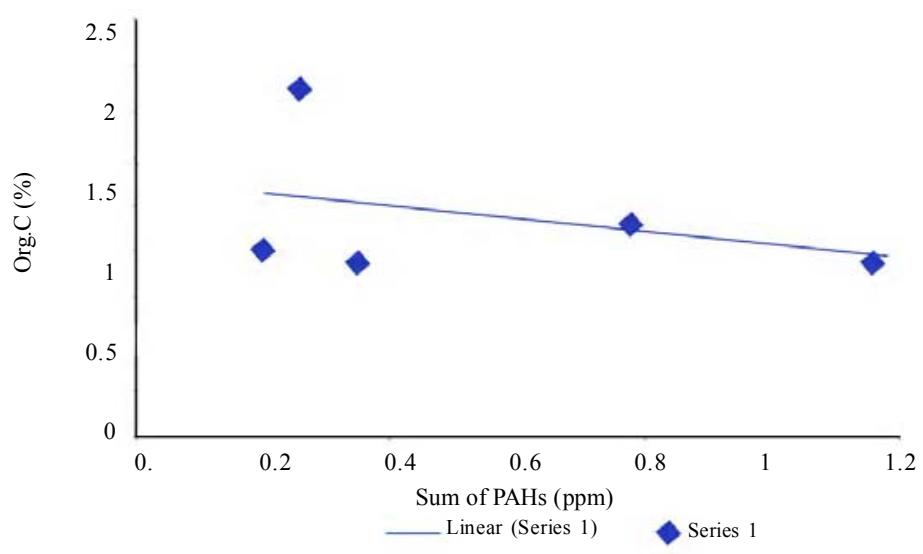

Fig. 3: Sediment wet season $\left(r^{2}=0.1345\right)$ 
Int. J. Environ. Sci. Tech., 7 (3), 561-570, Summer 2010

Table 7: Table of ratios of pahs from literature

\begin{tabular}{lll}
\hline PAHs & Ratio of PAHs & Inference \\
\hline PHEN/ANT & 3 & PAH arising from motor vehicle exhaust \\
PHEN/ANT & $>50$ & PAH arising from mineral oil \\
FLT/PYR & 1 & PAH probably formed by pyrolytic process \\
FLT/PYR & $>1$ & PAH probably formed by petrogenic process \\
$\mathrm{BaP} / \mathrm{PaP}$ & 1 & PAH arising from motor vehicle exhaust \\
$\mathrm{BaP} / \mathrm{PBE}$ & $0.2-0.5$ & PAH arising from motor vehicle exhaust \\
$\mathrm{BaP} / \mathrm{PBE}$ & $>1$ & PAH arising from coal combustion \\
$\mathrm{IND} / \mathrm{BPE}$ & 0.37 & PAH arising from traffic exhaust \\
PYR/BaP & $<1$ to 50 & PAH arising from diesel fuel-powered truck exhaust \\
NAPH/PHEN & $>1$ & PAHs derived from petrogenic sources \\
\hline
\end{tabular}

Source: Olajire and Brack, 2005

Some diagnostic elemental reported in literature, as shown in Table 7, were used to characterize the PAHs in this study. The ratios of the concentrations of PAHs in this study are shown in Tables 1 and 2. The ratio ofFLT/ PYR in OLSW1 (SED) in the wet season was 1.00 which shows that the PAHs are from pyrolytic process. The ratio of $\mathrm{BaP} / \mathrm{BPE}$ was 1.42 at OLSW2 (SED) in the wet season. This was greater than 1 showing that the PAHs are likely to come from coal combustion. This ratio was less than 3 indicating that these PAHs were not likely to come from motor vehicle exhaust and mineral oil. Sum of PAH concentrations above $1-10 \mu \mathrm{g} / \mathrm{kg}$ showed that PAHs may likely come from anthropogenic sources and not from plant synthesis and natural fires. This was as previously suggested by Edward (1983). $\Sigma$ PAH concentrations in sediments were between $0.02 \pm 01 \mathrm{ppm}$ and $0.12 \pm 0.06 \mathrm{ppm}$ in the dry season and between 0.18 $\pm 0.07 \mathrm{ppm}$ and $1.04 \pm 0.16 \mathrm{ppm}$ in the wet season. These values are higher than $\Sigma \mathrm{PAH}$ concentrations of $1-10 \mu \mathrm{g} /$ $\mathrm{kg}$ which indicate that the PAHs are from anthropogenic sources. This is in agreement with the findings of Olajire and Brack (2005).

\section{CONCLUSION}

This study depicts the present level of contamination of sediment with PAHs and PCBs at Agbabu bitumen deposit impacted area. No PCB was detected in the environment as at the time of this study but it is recommended that these toxic substances are investigated in the environment from time to time. Most of the concentrations of PAHs in sediment at Agbabu bitumen deposit area were lower than the recommended limits but naphthalene and benzo (a)pyrene were found to be present in sediment in the environment above the recommended limit. The PAHs were likely to be formed by anthropogenic processes such as pyrolysis and probably got to the environment by long range transport.
Though bitumen contains very small quantities of PAHs at 4-6 condensed carbon rings; they are not bioavailable. Higher concentrations were obtained in the wet season due to dilution and lower rates of degradation of PAHs. The predominant 4-6 rings PAHs present in this environment are known to be mutagenic and carcinogenic. The commencement of the exploitation of bitumen in the environment may likely release more of PAHs and PCBs to the environment by anthropogenic processes. The data obtained in this study can also be used as baseline data on Agbabu bitumen deposit area.

\section{ACKNOWLEDGMENTS}

Authors are grateful to the management of the University of Ado-Ekiti, Nigeria and the Department of Chemistry, University of Ado-Ekiti, for their cooperation. Mr. Uyi Hanson of the Rivers State University of Science and Technology, Port Harcourt and Miss Kate Iwuozor of Fugro laboratories, Port Harcourt are also appreciated for their assistance.

\section{REFERENCES}

Abass, A. A.; Abass, O. A.; Adejare, A. A.; Ojeyemi, M. D., (2007). Distribution of polycyclic aromatic hydrocarbons in surface soils and water from the vicinity of Agbabu bitumen field of south-western Nigeria. J. Environ. Sci. Heal. A., 42 (8), 1043-1049 (7 pages).

Adebiyi, F. M.; Asubiojo, O. I; Ajayi, T. R., (2006). Multielemental analysis of Nigerian bitumen by TXRF spectrometry and the physical constants characterization of its hydrocarbon content. Fuel., 85 (3), 396-400 (5 pages).

Adewole, M. G., (2010). Environmental implications of bitumen seep induced pollution in parts of Ogun state, southwestern Nigeria. Environ. Earth. Sci., 59 (7), 1507-1514 (8 pages).

Adeyemi D.; Ukpo G.; Anyakora C.; Uyimadu, J., (2009). Polychlorinated biphenyl in fish samples from Lagos Lagoon, Nigeria. Afr. J. Biotech., 8 (12), 2811-2815 (5 pages).

ATSDR, (2001). Polychlorinated Biphenyls. Agency for Toxic Substances and Disease Registry, ATSDR web page. http://www.atsdr.cdc.gov/tfacts17.html 
Akande, J. M., (2007). Environmental impact assessment of steam injection mining method of Agbabu bitumen deposit. J. Eng. Appl. Sci., 2 (10), 1497-1500 (4 pages).

Bitumen safety data sheet, (2008). Review. IES-Italiana Energia E. Servizi, Strada Cipata 7146100 Montova. http:// www.tosas.co.za/msds/MSDS_PenetrationGradeBitumen.pdf

Ciecierska, M.; Obiedzinski, M., (2007). Canned fish products contamination by polycyclic aromatic hydrocarbons. Acta Sci. Pol., Tech. Aliment., 6 (2), 19-28 (9 pages).

Clescery, L. S.; Greenberg, A. E.; Trussels R. R., (1989). APHA 6630c. Liquid-liquid extraction gas chromatographic method II. Standard methods for examination of water and waste water. $17^{\text {th }}$ ed. American Public Health Association American water works Association, Water Pollution Control Federation, 6-170-6-181.

Davies, O. A.; Abowei, J. F. N., (2009). Sediment quality of lower reaches of Okpoka creek, Niger Delta, Nigeria. Eur. J. Sci. Res., 26 (3), 437-442 (6 pages).

Edward, N. T., (1983). Polycyclic aromatic hydrocarbon (PAHs) in the terrestrial environment: A review. J. Environ. Qual., 12 (4), 427-441 (15 pages).

Elaine, A. L.; Herman, H., (2000). Multicomponent Analyte Determination, Gas Chromatography - USEPA Method 8270.

Fact sheet sources of polychlorinated biphenyls, (2003). Oregon Department of Environmental quality.- http:// www.deq.state.or.us/lq/cu/nwr/PortlandHarbor/docs/ SourcePCBs.pdf

Fagbote, E. O.; Olanipekun, E. O., (2010). Evaluation of the status of heavy metal pollution of sediment of Agbabu bitumen deposit area, Nigeria. Eur. J. Sci. Res., 41 (3), 373-382 (10 pages)

Fouial-Djebbar, D.; Badjah Hadji Ahmed, A. Y.; Budzinski, H., (2010). Determination of organochlorine compounds in coastal marine sediments from the southern west of the Mediterranean Sea. Int. J. Environ. Sci. Tech., 7 (2), 271 280 (10 pages).

Ho, H. H.; Swennen, R.; Van Damme, A., (2010). Distributions and contaminations status of heavy metals in estuarine sediments near Cua Ong harbor, Ha Long Bay, Vietnam. Geol. Belg., 13 (1-2), 37-47 (11 pages).

Jonsen, R. J.; Lukas, Y. W.; Harms H., (2005). Principles of microbial PAH-degradation in soil. Environ. Pollut., 133 (1), 71-84 (14 pages).

Juang, D. F.; Lee, C. H.; Hsueh, S. C., (2009). Chlorinated volatile organic compounds found near the water surface of heavily polluted rivers. Int. J. Environ. Sci. Tech., 6 (4), 545-556 (12 pages)

Kyn, B; Maung, A. T; Begum, B.; Haque, M.; Hemalika, S.; Sudrajat, H., (2009). Remediation of polycyclic aromatic hydrocarbons polluted soil using Fenton's reagent. J. Appl. Sci. Environ. Sanitation., V (N), 63-68 (6 pages).

Nagpal, N. K., (1994). Development of water quality and sediment criteria for PAHs to potent aquatic life. http://www.heb.pac.afo-mpo.ca/congress/1994/nagpal.pdf

Nnamchi, C. I.; Obeta, J. A. N.; Ezeogu, L. I., (2006). Isolation and characterization of some polycyclic aromatic hydrocarbon degrading bacteria from Nsukka soils in Nigeria. Int. J. Environ. Sci. Tech., 3 (2), 181-190 (10 pages).

Oboh, O. B.; Ilori, M. O.; Akinyemi, J. O.; Adebusoye, S. A. (2006). Hydrocarbon degrading potentials of bacteria isolated from a Nigerian bitumen (Tarsand) deposit. Nat. Sci., 4 (3), $51-58$ (8 pages).

Okafor, E. Ch.; Opuene, K., (2007). Preliminary assessment of trace metals and polycyclic aromatic hydrocarbons in the sediments. Int. J. Environ. Sci. Tech., 4 (2), 233-240 (8 pages).

Olajire, A. A.; Brack, N., (2005). Polycyclic aromatic hydrocarbons in Niger Delta soil contamination, sources and profiles. Int. J. Environ. Sci. Tech., 2 (4), 343-352 (10 pages).

Olajire, A. A.; Olujobade, M.; Olabemiwo, O., (2008). N-Alkane distribution in soil and water samples collected near Agbabu bitumen field of southwestern Nigeria. Int. J. Environ. Stud., 65 (6), 769-779 (11 pages).

Opuene, K.; Agbozu, I. E.; Ekeh, L. E., (2007). Identification of perylene in sediments: Occurrence and diagenetic evolution. Int. J. Environ. Sci. Tech., 4 (4), 457-462 (6 pages).

Prycek, J.; Ciganek, M.; Srinek, Z., (2007). Clean up of extracts for intracid derivatives of polycyclic aromatic hydrocarbons analysis prior their gas chromatography determination. J. Braz. Chem. Soc., 18 (6), 1125-1131 (6 pages).

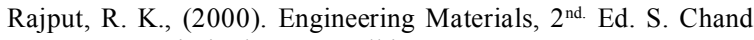
Company Limited, New Delhi.

Rauf, A.; Javed, M.; Ubaidullah, M.; Abdullah, S., (2009). Assessment of heavy metals in sediments of the river Ravi, Pakistan. Int. J. Agric. Biol., 11 (2), 197-200 (4 pages).

Soltanali, S.; Shams Hagani, Z., (2008). Modeling of air stripping from volatile organic compounds in biological treatment processes. Int. J. Environ. Sci. Tech., 5 (3), 353-360 (8 pages).

Teaf, C. M., (2008). Polycyclic aromatic hydrocarbons (PAHs) in urban soil; A Flourida risk assessment perspective. Int. J. soil. sed. water., 1 (2), 1-15 (15 pages).

Zhang, H.; Dang, Z.; Zheng, L. C.; Yi, X. Y., (2009). Remediation of soil co-contaminated with pyrene and cadmium by growing maize (Zea mays L.). Int. J. Environ. Sci. Tech., 6 (2), 249258 (10 pages).

AUTHOR (S) BIOSKETCHES

Fagbote, E. O., Ph.D. Candidate, Department of Chemistry, University of Ado-Ekiti, Nigeria. Email: bunmifag@yahoo.com

Olanipekun, E. O., Ph.D., Full Professor, Department of Chemistry, Unversity of Ado-Ekiti, Nigeria. Email: eddylapek@yahoo.com

How to cite this article: (Harvard style)

Fagbote, E. O.; Olanipekun, E. O., (2010). Levels of polycyclic aromatic hydrocarbons and polychlorinated biphenyls in sediment of bitumen deposit impacted area. Int. J. Environ. Sci. Tech., 7 (3), 561-570. 